\title{
PENYULUHAN PEMANFAATAN HERBAL PENCEGAH TINEA PEDIS PADA MASYARAKAT DI WILAYAH RAWAN BANJIR
}

\author{
Lia Yulia Budiarti ${ }^{1}$, Siti Kaidah ${ }^{2}$, Husnul Khatimah ${ }^{2}$, Erida Widyamala ${ }^{1}$ \\ ${ }^{11}$ Departemen Mikrobiologi Parasitologi, Fakultas Kedokteran Universitas Lambung Mangkurat \\ ${ }^{2}$ Departemen Biomedik Fakultas, Kedokteran Universitas Lambung Mangkurat \\ lybudiarti@ulm.ac.id, siti.kaidah@ulm.ac.id, khatynunul@gmail.comm
}

\begin{abstract}
Abstrak
Tinea pedis merupakan penyakit menular akibat infeksi jamur dan sering dialami oleh para pengungsi, karena keterlambatan pengobatan disaat bencana banjir. Kelurahan Sungai Lulut merupakan wilayah terbesar, yang terdampak bencana banjir di kota Banjarmasin pada Januari 2021. Banyak pengungsi dari wilayah ini mengalami kelainan tinea pedis, sehingga diperlukan pengetahuan pada masyarakat untuk mengenali dan memanfaatkan tanaman-tanaman berkhasiat obat, yang ada di lingkungan masyarakat bantaran sungai dan di wilayah rawan banjir. Kegiatan PKM ini bertujuan memberikan penyuluhan tentang jenis herbal dan pemanfaatannya untuk mencegah penyakit tinea pedis pada masyarakat di Kelurahan Sungai Lulut. Kegiatan penyuluhan dilaksanakan secara luring dengan mitra sasaran adalah ibu-ibu rumah tangga. Evaluasi dinilai berdasarkan jawaban pada kuosioner sebelum dan sesudah kegiatan PKM. Hasil kegiatan, didapatkan lebih dari 90\% mitra sasaran dapat mengenal jenis herbal yang dapat dimanfaatkan untuk mengatasi tinea pedis. Kesimpulan kegiatan penyuluhan dapat meningkatkan pengetahuan mitra sasaran dalam mengenali dan memanfaatkan jenis herbal untuk mencegah penyakit tinea pedis. Diharapkan pada mitra sasaran yang telah mendapat penyuluhan dapat mempraktekkannya, serta kegiatan serupa dapat dikembangkan lebih lanjut pada masyarakat lainnya.
\end{abstract}

Kata Kunci : banjir, herbal, Kelurahan Sungai Lulut, tinea pedis

\section{PENDAHULUAN}

Banjir merupakan suatu kondisi fenomena bencana alam ke tiga terbesar di dunia serta memiliki hubungan dengan jumlah kerusakan dari sisi kehidupan dan material. Bencana banjir menimbulkan banyak menelan korban jiwa dan kerugian harta benda. Dampak bencana banjir juga menyenyebab kerusakan sistem sanitasi dan air bersih, serta berpotensi menimbulkan berbagai penyakit yang ditularkan melalui media air (water-borne diseases) seperti diare leptospirosis, dan mikosis tinea pedis.

Bencana banjir yang diikuti dengan pengungsian berdapotensi menimbulkan permasalahan kesehatan masyarakat dan berdampak pada menurunnya kualitas hidup penduduk. Kondisi lingkungan yang tidak higienis, persediaan air yang terbatas dan jamban yang tidak memadai, seringkali menjadi penyebab 
korban bencana lebih rentan untuk mengalami penyakit tertentu. Buruknya kehersihan diri dan sanitasi lingkungan merupakan awal dari perkembangbiakan beberapa jenis penyakit menular (The Sphere Project, 2011; Meinisa, 2017).

Pada saat terjadi bencana, tempat / posko pengungsian yang ada sering tidak memenuhi syarat kesehatan, sehingga secara langsung maupun tidak langsung dapat menurunkan daya tahan tuhuh dan bila tidak segera ditanggulangi akan menimhulkan masalah kesehatan masyarakat. Perilaku para pengungsi selama banjir yang kurang sehat seperti cuci tangan dan kaki dengan air tanpa sabun, dapat menurunkan status kesehatan seseorang (Harthan \& Oedjo, 2014). Sementara itu, pemberian pelayanan kesehatan pada kondisi hencana sering menemui hanyak kendala akibat rusaknya fasilitas kesehatan, akses jalan yang terputus, tidak memadainya jumlah dan jenis ohat serta alat kesehatan, terhatasnya tenaga kesehatan dan dana operasional. Kondisi ini dapat menimbulkan dampak lehih buruk bila tidak segera ditangani (Faiqoh et all., 2017; Kemenkes, 2019).

Musim hujan yang berkepanjangan selama November 2020 sampai akhir Januari 2021 di seluruh Kalimantan Selatan, termasuk di Kota Banjarmasin, menyebabkan bencana banjir bandang dengan puncak bencana yang terjadi pada awal Januari 2021. Salah satu wilayah kelurahan di Banjarmasin yang paling terdampak luas akibat bencana banjir adalah di Kelurahan Sungai Lulut. Wilayah ini secara topografis merupakan wilayah bantaran sungai serta wilayah rawan banjir. (BPBD Kota Banjarmasin, 2021).

Hasil analisis situasi lapangan, memperlihatakan banjir tahun Januari 2021 ini merupakan banjir terbesar yang dialami masyarakat Sungai Lulut, selain menimbulkan dampak terhadap lingkungan perumahan menjadi rusak dan kotor, terbatasnya sarana air bersih. Selain itu juga berdampak pada kesehatan para pengungsi. Informasi masyarakat, diatara para pengungsi banjir yang menempati Sekolah Dasar Negeri SDN

5 Sungai Lulut, menderita kelainan gatal-gatal dan meradang pada bagian kulit kaki dan dan badannya; masyarakat mengenal kelainan kulit ini sebagai penyakit kutu air atau tinea pedis. Masyarakat juga mengeluhkan pada saat terjadi bencana banjir, mengalami kesulitan dalam mendapat pengobatan, karena terputusnya akses jalan ke pusat kesehatan serta keterbatasan obat-obatan di puskesmas terdekat. Disisi lain pengetahuan masyarakat menggunakan obat alternatif/ herbal masih kurang.

Penyakit tinea pedis, yang dikenal oleh masyarakat umum sebagai penyakit kutu air dan diangap sebagai penyakit yang disebabkan oleh kutu/serangga yang hidup di air hujan. Presepsi yang keliri ini, perlu diluruskan sehingga masyarakat lebih mengenal jenis penyebab dan cara mengatasi penyakit tinea pedis. Penyakit tinea pedis, merupakan hal yang umum sering terjadi disaat bencana banjir, karena bagian kaki merupakan bagian utama dari tubuh yang sering bersentuhan dan terendam air kotor. Keluhan yang biasanya dirasakan saat seseorang mengalami penyakit ini adalah kulit kaki yang terasa gatal, bersisik, dan kemerahan (Sahoo \& Mahajan, 2016).

Disaat terbatasnya ketersediaan obat-obatan sintetis, maka solusinya yaitu dengan memanfaatkan herbal dsebagai pengobatan alternatif. Namun, informasi jenis herbal yang dapat digunakan untuk mengatasi tinea pedis ini, sangat minim. Berlandaskan permasalahan yang dihadapi masyarakat di Kelurahan Sungai Lulut ini, maka perlu ditindak lanjuti dengan suatu kegiatan penyuluhan yang sesuai. Kegiatan penyuluhan dapat meningkatkan pemahaman, kepedulian dan peran masyarakat dalam mengatasi suatu penyakit dengan memanfaatkan sumber alam disekitarnya.

Bencana banjir yang senantiasa memiliki potensi untuk kembali terjadi diwilayah bantaran sungai Lulut, sehingga dipilih penyuluhan mengenai jenis herbal yang dapat dimanfaatkan dalam mengatasi penyakit tinea pedis. Tujuan dari PKM ini yaitu memberikan penyuluhan tentang jenis herbal dan pemanfaatannya untuk mencegah 
penyakit tinea pedis pada masyarakat di Kelurahan Sungai Lulut. Target capaian dari kegiatan penyuluhan ini adalah lebih dari $90 \%$ peserta penyuluhan mengenal jenis herbal yang dapat dimanfaatkan untuk mengatasi tinea pedis.

\section{METODE}

Kegiatan penyuluhan ini dilaksanakan secara tatap muka langsung /luring pada tanggal 18 Juni 2021, bertempat di Langgar Ar-Rahman Kelurahan Sungai Lulut. Target sasaran kegiatan adalah masyarakat yang terdampak banjir. Sasaran terpilih adalah ibu-ibu rumah tangga di RT 28 di Kelurahan Sungai Lulut, yang dipilih oleh pihak RT setempat. Letak RT 28 ini merupakan perbatasan anatara Kota Banjarmasin dengan Kabupaten Banjar, sebagai wilayah yang paling rawan mendapat banjir bandang. Sasaran terpilih, selain terdampak banjir, juga aktif dalam kegiatan pengajian/ yasinan. Hal ini dilakukan agar peserta aktif dan dapat mensosialisasikan hasil keluarganya dan masyarakat lainnya. Jumlah peserta yang aktif mengkuti kegiatan penyuluhan ini adalah sebanyak 30orang.

Kegiatan penyuluhan ini dilaksanakan
beberapa tahapan yaitu: 1) Tahap perencanaan, dimulai dengan dibentuknya tim pengabdian serta dirancangnya proposal kegiatan; 2) Tahapan survei lokasi dan analisis situasi permasalahan di wilayah sasaran; 3) Pertemuan awal dengan RT setempat, menyampaikan maksud dan tujuan penyuluhan; 4) Sosialisasi, koordinasi serta kesepakatan pelaksaan penyuluhan dengan beberapa sasaran IRT; 5) Tim pelaksana penyuluhan menentapkan time frame kegiatan dan design pengabdian, 6) Mempersiapkan instrument dan media kegiatan penyuluhan, 7) Penyusunan jadwal acara dan administrasi kegiatan penyuluhan; dan 8) pelaksanaan penyuluhan serta evaluasi kegiatan.

Penyuluhan dilakukan dengan metode ceramah dan tanya jawab. Materi penyuluhan pada kegiatan penyuluhan ini disampaikan secara sederhana, informatif dan menarik dengan menggunakan media-media LCD, leafleat, dan poster. Materi yang disampaikan yaitu: 1) Penyakit tinea pedis: penyebab, tanda dan gejala; 2) Pencegahan tinea pedis; serta 3) Jenis herbal untuk mengatasi tinea pedis. Evaluasi terhadap keberhasilan penyuluhan ini diperoleh dari jawaban kuisioner peserta sebelum (pre-test) dan setelah (post-test) kegiatan penyuluhan.

\section{HASIL DAN PEMBAHASAN}

Wilayah bantaran sungai Lulut, Kelurahan Sungai Lulut, Kecamatan Banjarmasin Timur merupakan wilayah rawan banjir. Dampak banjir yang luas menimbulkan berbagai permasalahan di lingkungan masyarakat ini, diantaranya adalah permasalahan kesehatan yang muncul pada para pengungsi yaitu penularan penyakit tinea pedis. Berdasarkan hasil analisis situasi lingkungan dan survei pendahuluan, dilingkungan masyarakat Sungai Lulut, didapatkan lingkungan perumahan masyarakat yang masih tergenang air banjir, tetapi disis lain masih didapatkan berbagai jenis tanaman. Jenis tanaman berkhasiat obat/ herbal yang ada dilingkungan masyarakat, dapat dimanfaatkan untuk mengatasi berbagai penyakit, termasuk tinea pedis. Berlandasan analisis situasi permasalahan lingkungan masyarakat yang ada, maka dilaksanakan kegiatan penyuluhan ini. Berikut gambar-gambar persiapan dan penyampaian materi penyuluhan, serta suasana kegiatan penyuluhan.

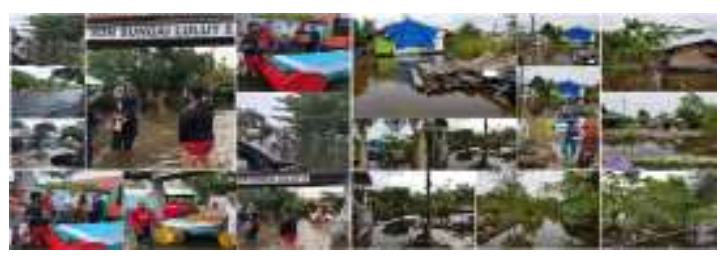

Gambar 1. Suasana situasi banjir di Kelurahan Sungai Lulut Banjarmasin

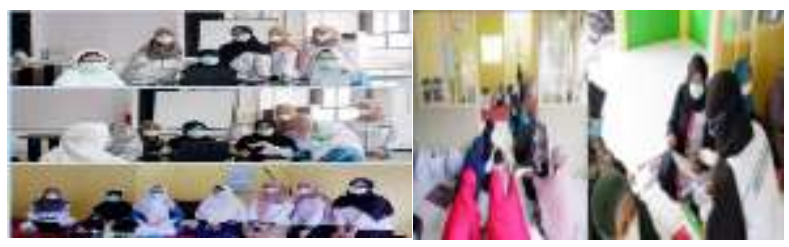

Gambar 2. Persiapan dan pelaksana penyuluhan 


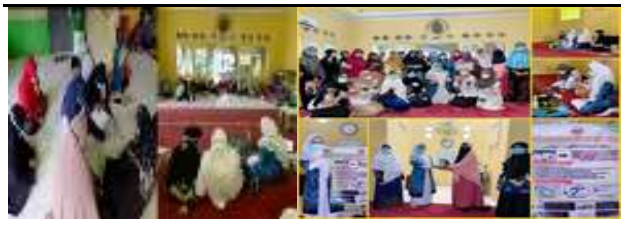

Gambar 3. Suasana kegiatan penyuluhan

Masyarakat/peserta kegiatan penyuluhan, awalnya mengira penyebab tinea pedis adalah kutu /jenis serangga yang biasa hidup di air dan menyerang di saat musim hujan atau saat banjir. Setelah diberikan informasi melalui penyuluhan, peserta mengerti bahwa penyebab tinea pedis/ kutu air adalah jenis jamur yang menyerang kulit. Semakin tinggi genangan air banjir dan semakin lama banjir, maka akan mengakibatkan semakin lama warga masyarakat untuk kontak dengan air genangan akibat banjir tersebut. Sehingga, berbagai mikroorganisme yang berada pada genangan air pada saat banjir tersebut dapat masuk ke dalam tubuh jika bagian tubuh tersebut terendam lama pada air yang terinfeksi yaitu masuk melalui luka atau pori-pori.

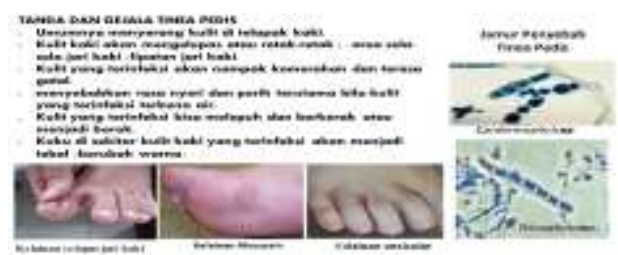

Gambar 4. Tanda, gejala, penyebab dan jenis kelainan tinea pedis

Tinea pedis merupakan penyakit menular akibat infeksi jamur dan sering dialami oleh para pengungsi, karena keterlambatan pengobatan disaat terjadi bencana banjir. Penyakit ini dapat meyerang semua usia, umumnya penyakit dimulai dari kelainan di jari kaki, tetapi dapat dengan cepat menyebar ke seluruh permukaan kaki, naik keatas kunci paha, dan menyebar ke seluruh tubuh. Tinea pedis umumnya disebabkan oleh jenis jamur Trichophyton rubrum, Trichophyton mentagrophytes, dan Epidermophyton floccosum (James, et al., 2011). Terdapat tiga jenis kelainan tinea pedis (Gambar 4) yaitu: infeksi selaput jari kaki, infeksi Moccasin, dan infeksi vesicular. Infeksi selaput jari kaki terjadi pada bagian selaput di antara jari-jari kaki. Kondisi ini ditandai dengan kulit bersisik yang mengelupas dan pecah. Jenis infeksi Moccasin ditandai dengan pecahnya telapak kaki. Jenis infeksi vesikular ditandai dengan wabah melepuh pada kaki (James, et al., 2011; Bolognia et all., 2012; Sahoo \& Mahajan, 2016).

Penularan tinea pedis, dapat melalui kontak langsung maupun tidak langsung; kontak langsung misalnya ketika seseorang menyentuh bagian kulit penderita penyakit ini; sedangkan kontak tidak langsung dapat terjadi melalui penggunaan benda yang telah terkontaminasi jamur seperti pakaian, handuk, sepatu, kaus kaki, sandal dan lain-lain. Penularan secara tidak langsung juga dapat terjadi karena kaki terendam air hujan/ air banjir, berjalan tanpa alas kaki di lantai kamar mandi, pemandian umum.

Pada saat terjadi wabah banjir media air banjir dan penggunaan kamar mandi umum di tempat/rumah pengungsi menjadi sebab cepatnya penularan penyakit seperti tinea pedis diantara para pengungsi. Pencegahan penyakit yang ditularkan melalui dapat dilakukan dengan melakukan perilaku cuci tangan dengan zat antiseptik, menggunakan air bersih dan mengalir (Budiarti, et al.,2017). Penggunaan air hangat yang ditambah garam untuk merendam kaki yang sakit, umumnya dapat meredakan sementara penyakit tinea pedis. Tindakan pencegahan selanjutnya yaitu untuk memperhatikan kebersihan kaki, menjaga kaki tetap kering, membersikan kuku kaki, menggunakan sepatu yang pas dan kaos kaki kering dan bersih, serta menggunakan sandal pada tempat mandi umum atau kolam renang (James, 2011; Tainwala \& Sharma, 2011).

Upaya sederhana dalam mengatasi penyakit menular dalam masyarakat adalah membiasakan perilaku hidup bersih dan sehat (PHBS). Masih banyak masyarakat yang belum menyadari akan manfaatnya melaksanakan pembiasaan PHBS ini, termasuk dalam kondisi darurat atau bencana. Sehingga penyuluhan PHBS perlu tetap disosialisasikan pada masyarakat. Berapa upaya mencegah penularan penyakit di wilayah banjir, yaitu memaksimalkan penggunaan alat pelindung diri, seperti sepatu boots, sarung tangan karet, masker dan kacamata pelindung (Kemenkes RI, 
2019). Alat pelindung diri ini berfungsi agar warga terhindar dari penyakit yang timbul dari adanya bencana banjir seperti infeksi jamur kulit, atau penyakit dari luka benda tajam dan penyakit menular lainnya (Harthan \& Oedjo, 2014). Upaya yang penting dilakukan oleh masyarakat setelah/pasca banjir diantaranya membersihkan rumah dan lingkungan dengan cara menyapu lantai, mengepel lantai menggunakan bahan disinfeksi pembersih lantai, menyediakan tempat sampah dan membuang sampah di tempat sampah (Harthan \& Oedjo, 2014).

Pengobatan secara sintetis untuk mengatasi tinea pedis umumnya menggunakan antijamur topikal golongan alilamin, imidazol, siklopiroks, benzilamin dan tolnaftate (Tainwala \& Sharma, 2011; Sahoo \& Maharajan, 2016). Tinea pedis yang tidak diobati atau diobati dengan tidak benar akan menyebabkan berbagai komplikasi seperti selulitis, tinea unguium serta dermatofid (Bolognia et all., 2012).

Hasil tanya jawab pada kegiatan penyuluhan, umumnya masyarakat mengatasi tinea pedis dengan menggunakan obat salep yang diperoleh dari puskesmas atau yang dijual bebas. Penggunaan obat-obatan sintetis jangka lama dapat menyebakan kulit meradang lebih luas serta terjadinya resistensi jamur penyebab. Sehingga diperlukan obat alternatif alami yang lebih aman. Obat alternatif berupa herbal yang tumbuh di lingkungan masyarakat, dapat mudah dikenal oleh masyarakat. Namun, umumnya pengetahuan masyarakat akan khasiat tanaman sebagai herbal masih kurang. Informasi mengenai khasiat herbal hasil-hasil penelitian, dapat disampaikan kepada masyarakat melalui kegiatan penyuluhan.

Berdasarkan hasil diskusi, masih banyak masyarakat yang belum mengetahui adanya herbal/tanaman obat yang dapat dimanfaatkan untuk mengatasi tinea pedis. Pada kegiatan penyuluhan ini diinformasikan jenis herbal yang umunya terdapat dilingkungan rumah atangga/masyarakat dan penggunaannya secara mudah dan sederhana untuk mengatasi penyakit tinea pedis. Berikut pengetahuan peserta penyuluhan dalam mengenal jenis herbal pencegah penyakit tinea pedis.
Tabel 1. Pengetahuan peserta penyuluhan tentang jenis herbal pencegah penyakit tinea pedis

\begin{tabular}{ccccc}
\hline Pengetahuan & \multicolumn{2}{c}{ Pre Test } & \multicolumn{2}{c}{ Post Test } \\
\cline { 2 - 5 } & $\begin{array}{c}\text { Jumlah } \\
\text { peserta }\end{array}$ & $\%$ & $\begin{array}{l}\text { Jumlah } \\
\text { peserta }\end{array}$ & $\%$ \\
\hline Baik & 0 & 0,0 & 30 & 100 \\
\hline Cukup & 12 & 40,0 & & \\
\hline Kurang & 18 & 60,0 & & \\
\hline Jumlah & 30 & 100 & 30 & 100 \\
\hline
\end{tabular}

Tabel 1, memperlihatkan hasil jawaban kuisioner dari peserta penyuluhan, Pengetahuan peserta sebelum penyuluhan adalah kurang sampai cukup baik, sedangkan setelah penyuluhan didapatkan $100 \%$ peserta memilki pengetahuan yang baik. Terdapat peningkatan pengetahuan peserta setelah mendapatkan materi penyuluhan ini (post-test) dalam mengenali jenis herbal dan penggunannya dalam mengatasi tinea pedis). Dari hasil kegiatan penyuluhan ini, maka target capaian penyuluhan tercapai. Pentingnya pengetahuan bagi masyarakat dalam mengenali jenis herbal dalam mengatasi suatu penyakit, yang dapat diaplikasikan pada berbagai kondisi/keadaan.

Banyak jenis tanaman obat/herbal yang ada disekitar lingkungan masyarakat untuk dimanfaatkan dalam mengatasi tinea pedis. Beberapa jenis herbal dan cara penggunaanya yang disampaikan pada penyuluhan ini, tampak pada Gambar 5, yaitu: 1) Daun sirih ; 2) Daun Salam; 3) Bawang putih; 4) Daun Sambiloto; 5) Daun Jarak pagar; 6) Daun Patikan kebo; 7) Daun talas; 8) Lengkuas merah, dan 9) Singkong.

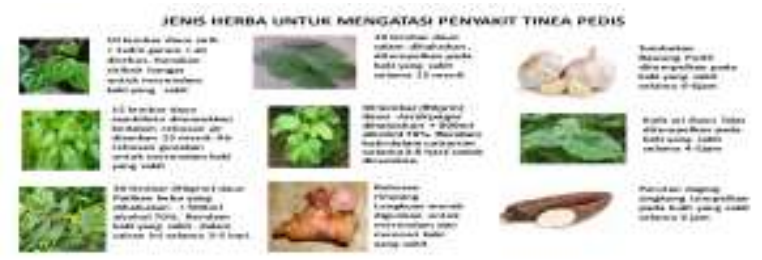

Gambar 4. Materi penuluhan jenis herba untuk mengatasi penyakit tinea pedis. 
Pengobatan yang lebih efektif, dapat menggunakan berbagai jenis tanaman obat/ herbal yang dengan mudah didapatkan di sekitar lingkungan masyarakat. Beberapa hasil penelitian telah membuktikan jenis herbal yang memiliki kandungan berbagai senyawa sekunder yang berkhasiat sebagai antijamur. Senyawa anti jamur yang umum terkandung dalam sediaan herbal adalah flavonoid dan fenolik yang mengandung gugus fenol. Kandungan senyawa flavonoid dan fenol, terdapat pada daun sirih (Kusumaningtyas, 2018; Kurnia, 2020); daun salam (Harismah, K., 2017); daun sambiloto (Arief, et al., 2016); daun jarak pagar (Ningsi \& Fadhilah, 2017); daun patikan kebo (Zulkarnain et al., 2019); daun talas (Dewangga, et al., 2017), rimpang lengkuas (Sarni, et al., 2013), dan juga terkandung dalam singkong (Naldi \& Aisyah, 2014; Zulkarnain, et. al., 2019; Hasanah, et all., 2020). Kandungan antifungi dalam bawang putih adalah alicin (Martínez, et. al., 2019).

Mekanisme kerja senyawa antijamur, seperti flavonoid yaitu mengganggu pembentukan pseudohifa selama proses perkembangan jamur. Flavonoid membentuk kompleks dengan protein ekstraseluler dan terlarut dengan dinding sel, sehingga dapat menyebabkan denaturasi protein dinding sel yang akhirnya dapat menyebabkan kerapuhan dinding sel jamur (Kusumaningtias, et al., 2018). Mekanisme kerja senyawa fenol yaitu dapat membentuk kompleks dengan ergosterol yang terdapat dalam membran sel jamur, kompleks tersebut menyebabkan pori-pori membesar pada sel jamur. Lewat pori-pori inilah komponen kecil dari isi sel jamur keluar seperti asam nukleat dan protein lainnya. Hal tersebut bila terus berlangsung akan menyebabkan kematian jamur. Fenol juga mempunyai kelarutan yang tinggi pada lipid, maka efek terbesar fenol adalah kemampuanya bergabung dengan komponen lipid sel. Membran sel pada jamur tersusun atas fosfolipid yang akan menyebabkan permeabilitas membran sel terganggu sehingga pertumbuhan jamur terhambat. Fenol dalam konsentrasi tinggi, akan merusak membran sitoplasma secara total dan mengendapkan protein sel, dan menyebabkan bocornya metabolit penting sel jamur (Kusumaningtias; 2018; Al-Kaff, et al., 2019; Zulkarnain, et all., 2019).
Bawang putih mengandung senyawa allin yang bekerja mengaktifkan enzim alliinase; enzim ini membantu proses metabolisme allicin yang tekandung dalam sel lain. Allicin, selanjutnya direduksi menjadi senyawa antimikroba deoksialliin, dialyl disulfida (DADS) dan diallyl trisulfida (DATS). Alilicin bekerja dengan cara mereduksi sistein dalam sel mikroba, sehingga mengganggu ikatan disulfida dalam protein dan menggangu proses pembentukan protein sel mikroba (Martinez, et al., 2019)

Semua peserta penyuluhan aktif menyimak dan terlibat dalam diskusi. Hasil kegiatan penyuluhan ini dapat dikatakan berhasil meningkatkan pengetahuan peserta/mitra sasaran, dengan capaian target lebih dari 90\%. Hal ini dipengaruhi oleh informasi mengenai jenis herbal pencegah infeksi tinea pedis yang ada dan mudah didapat disekitar lingkungan masyarakat, sehingga semua peserta penyuluhan mudah mengenalinya; selain itu penggunaan herbal untuk mengatasi penyakit ini dapat dengan mudah dibuat dan sederhana. Kegiatan penyuluhan berkaitan dengan pemanfaatan herbal/ tanaman obat pada masyarakat perlu terus disosialisasikan, mengingat kekayaan tanaman herbal Indonesia, termasuk di Kalimantan Selatan yang melimpah, tetapi informasi akan khasiatnya belum banyak diketahui oleh masyarakat. Diharapkan pengetahuan yang diperoleh dari kegiatan penyuluhan ini dapat diterapkan secara kontinyu dalam kehidupan sehari-hari serta disosialisasikan pada masyarakat wilayah bantaran sungai dan rawan banjir lainnya.

\section{KESIMPULAN}

Kegiatan penyuluhan ini dapat meningkatkan pengetahuan mitra sasaran dalam mengenali dan memanfaatkan jenis herbal untuk mencegah penyakit tinea pedis. Diharapkan pada mitra sasaran yang telah mendapat penyuluhan dapat mempraktekkannya, serta kegiatan serupa dapat dikembangkan lebih lanjut pada masyarakat lainnya 


\section{UCAPAN TERIMAKASIH}

Ucapan terimakasih disampaikan kepada Fakultas Kedokteran Universitas Lambung Mangkurat yang telah memberikan bantuan dana untuk pelaksanaan kegiatan penyuluhan ini, melalui hibah PKM FK ULM tahun anggaran 2021.

\section{REFERENSI}

Al-Kaf, A. G.., A. M T. Al-Deen., S. A. A. Alhaidari dan F. A, Al-Hadi. (2019). Phytochemical Analysis and Antimicrobial Activity of Colocasia esculenta (Taro) Medicinal Plant Leaves Used in Folk Medicine for Treatment of Wounds and Burns in Hufash District Al Mahweet Governorate \pm Yemen. Universal Journal of Pharmaceutical Research. 4 (2), 29-33

Arief, N., Esti, R., Dimas, B. W., \& Rendro, W. (2016). Pengaruh Ekstrak Daun Sambiloto (Andrographis paniculata (Burm.F)Ness) Terhadap Daya Bunuh Bakteri Leptospira sp. Media Litbangkes. 77-8

BPBD Kota Banjarmasin. (2021). Kondisi Kota Banjarmasin dan Penggulangan bencama Banjir".

Bolognia, J.L., Jorizzo L, Rapini R.P. (2012). Dermatology. Tinea Pedis. 3rd ed. British Library. 19-21

Budiarti L.Y., L. khariyati, R. Fakhriyadi. (2017). The Relationship Between The Existence of Bacterial Type From Hand and Feces With Water Paping on Elementary School Students on The Riverbanks. Proceeding International Seminar Development of Tropical Diseases Research Based on Wetland and Indonesian Local Wisdom. Banjarmasin. ISSN.24773522: $336-347$

Dewangga A., S. F. Meirani, R. Apriliany, U. A. Darojati, A.I. Yudha. (2017). Formulasi Tablet Effervecent Dari Ekstrak Etanol Daun
Talas (Colocasia esculenta L.) Sebagai Antiseptik Topikal Biomedika, 9 (2): 1-5.

Faiqoh, F., Sulistiyani \& Budiyono. (2017). Analisis hubungan tingkat kerentanan penduduk wilayah pantai Kota Semarang akibat banjir rob dengan status kesehatan. Jurnal Kesehatan Masyarakat, 5(5), 649-658.

Hasanah N., I. Nursobah, N.W.A. Ismaya. (2020). Toksisitas Ekstrak Umbi Singkong (Manihot esculanta Crantz) . Edu Dharma Journal. 4(1): 87-96.

Harismah, K. (2017). Pemanfaatan Daun Salam (Eugenia polyantha) Sebagai Obat Herbal Dan Rempah Penyedap Makanan. Warta LPM. 19(2):110.

Harthan, T., \& Oedjo, S. (2014). Faktor determinan perilaku cuci tangan pakai sabun saat banjir Bengawan Solo di Bojonegoro. Review Literatur: Jurnal Promosi kesehatan, 2(2), 160-172.

James WD, Elston DM \& Berger TG. Andrew's (2011). Disease of the Skin: Clinical Dermatology, ed 11th. Spain: Saunders Elsevier. 10: 188-189.

Kemenkes RI. (2019). Peraturan Menteri Kesehatan Tentang Standar Teknis Pemenuhan Mutu Pelayanan Dasar Pada Standar Pelayanan Minimal Bidang Kesehatan . Peraturan Menteri Kesehatan NO. 4, BN.2019/NO.68, kemkes.go.id : $6 \mathrm{hlm}$.

Kusumaningtyas E, Widiatri R, Gholib D. (2018). Uji daya hambat ekstrak dan krim ekstrak daun sirih (Piper betle) terhadap candida albicans dan trichophyton mentagrophytes. In: Seminar Nasional Teknologi dan Veteriner. 805- 11 .

Martínez, M.R, J.F González, F. J. PérezVázquez, J.M.Carrizales, E. Pérez, R. P. Herrera. (2019). Antimycotic Activity

Kesehatan 520 
Potentiation of Allium sativum Extract and Silver Nanoparticles against Trichophyton rubrum. Chemistry \& Biodiversity. https://doi.org/10.1002/ cbdv.201800525

Meinisa, E. T. (2017). Pola tindakan dalam mengatasi masalah kesehatan masyarakat korban banjir. Jurnal sosial dan politik, 119.

Kurnia, M. (2020). Efek Pemberian Daun Sirih Hijau Terhadap Pertumbuhan Candida albicans. Medula. 10:2. 197-201.

Naldi Y, I.S. Aisah. (2014). Perbandingan Efekstivitas Lengkuas Meraha (Alpinia K.Schum) dan Lengkuas Putih (Alpinia galanga) Terhadap Pertumbuhan Jamur Candida albicans. Tunas Medika Jurnal Kedokteran \& Kesehatan. 1-4.

Ningsi S., R.N. Fadhilah. (2017). Uji Aktivitas Antimikroba Ekstrak Daun Jarak Pagar (Jatropha curcas .Linn) Terhadap Jamur Penyebab Kutu Ai . JF FIK UINAM. 5 (1 ) 46-51.

Sahoo, A.K \& R. Mahajan. (2016). Management of tinea corporis, tinea cruris, and tinea pedis: A comprehensive review. Indian Dermatol Online J. 7(2): 77-86.

Salni, N. A., R. Sriviona. (2013). Semirata Isolasi Senyawa Antijamur Dari Rimpang Lengkuas Putih (Alpinia galanga (L.) Willd) dan Penentuan Konsentrasi Hambat Minimum Terhadap Candida albicans. Prosiding FMIPA UNILA. 301-7.

Tainwala, Ram dan YK Sharma. (2011). Pathogenesis of Dermatophytoses. Indian J Dermatol. 56(3):259-261.

The Sphere Project. (2011). Humanitarian charter and minimum standards in humanitarian response. 3rd ed. Southampton: The Sphere
Project.

Zulkarnain, C. M., Fatmawati Nur, R. Rukmana. (2019). Efektivitas Antifungi Ekstrak Daun Patikan Kebo (Euphorbia hirta) Terhadap Jamur Penyebab Kandidiasis. Al-Hayat: Journal of Biology and Applied Biologi. 2. (1): 22-27. 